BNL 51056

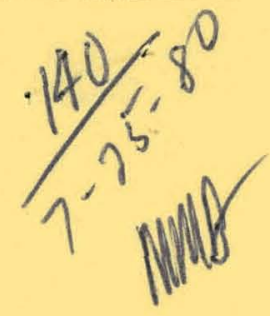

\title{
THE BROOKHAVEN INTEGRATED ENERGY/ECONOMY MODELING SYSTEM AND ITS USE IN CONSERVATION POLICY ANALYSIS
}

Paul J. Groncki and William Marcuse

July 1979

NATIONAL CENTER FOR ANALYSIS OF ENERGY SYSTEMS DEPARTMENT OF ENERGY AND ENVIRONMENT

$\checkmark$ BROOKHAVEN NATIONAL LABORATORY UPTON, NEW YORK 11973

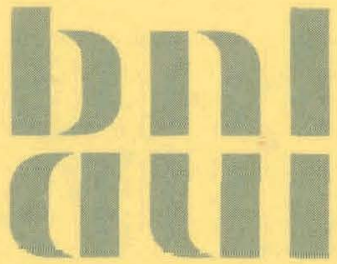




\section{DISCLAIMER}

This report was prepared as an account of work sponsored by an agency of the United States Government. Neither the United States Government nor any agency Thereof, nor any of their employees, makes any warranty, express or implied, or assumes any legal liability or responsibility for the accuracy, completeness, or usefulness of any information, apparatus, product, or process disclosed, or represents that its use would not infringe privately owned rights. Reference herein to any specific commercial product, process, or service by trade name, trademark, manufacturer, or otherwise does not necessarily constitute or imply its endorsement, recommendation, or favoring by the United States Government or any agency thereof. The views and opinions of authors expressed herein do not necessarily state or reflect those of the United States Government or any agency thereof. 


\section{DISCLAIMER}

Portions of this document may be illegible in electronic image products. Images are produced from the best available original document. 


\title{
THE BROOKHAVEN INTEGRATED ENERGY/ECONOMY MODELING SYSTEM AND ITS USE IN CONSERVATION POLICY ANALYSIS
}

\author{
Paul J. Groncki and William Marcuse
}

July 1979

ECONOMIC ANALYSIS DIVISION

\section{NATIONAL CENTER FOR ANALYSIS OF ENERGY SYSTEMS DEPARTMENT OF ENERGY AND ENVIRONMENT BROOKHAVEN NATIONAL LABORATORY ASSOCIATED UNIVERSITIES, INC.}

UNDER CONTRACT NO. DE-AC02-76CH00016 WITH THE UNITED STATES DEPARTMENT OF ENERGY 


\section{DISCLAIMER}

This book was prepared as an account of work sponsored by an agency of the United Etates Government: Neither the Unitod \&eateo Govornmont nor any agonoy thoroof, nor any of their employees, makes any warranty, express or implied, or assumes any legal liability or responsibility for the accuracy, completeness, or usefulness of any information, apparatus, product, or process disclosed, or represents that its use would not infringe privately nwned rights Reference herein th any aperific commerrial prod: uct, process, or service by trade name, trademark, manufacturer, or otherwise, does not necessarily constitute or imply its endorsement, recommendation, or favoring by the United States Government or any agency thereof. The views and opinions of authors expressed herein do not necessarily state or reflect those of the United States Government or any agency thereof.

Printed in the United States of America Available from

National Technical Information Service

U.S. Department of Commerce 5285 Port Royal Road Springfield, VA 22161

Price: Printed Copy $\$ 4.50 ;$ Microfiche $\$ 3.00$ 
The approach used at Brookhaven National Laboratory to model the impact of the introduction of advanced energy technologies in response to Increased energy prices has been to link econometric, process, and inputoutput models. The econometric model generates growth, employment, productivity, Inflation, final demand, and price-determined input-output coefficients for a ten-sector interindustry model. The outputs from the six energy sectors are used to drive a national energy process model which supplies energy prices, fuel $\mathrm{mix}$, and energy capital requirements to the econometric model. The four nonenergy final demands from the econometric model are disaggregated and used with the energy demands from the process model to drive a 110-sector input-output model. The nonenergy coefficients in the input-output model are fixed, but the energy coefficients are variable reflecting the technologies chosen by the solution of the process model. Coefficients representing advanced energy technology production functions have been incorporated in the inputoutput structure.

This approach is briefly described. Three applications of this set of 11nked models are presented. The first presentation reports the findings of a study of the effects of various levels of conservation on the rate of growth in GNP and other economic indicators. The second presentation describes an application of the linked models to an accelerated solar technology scenario; this study is focused on the long-run macroeconomic impacts of increased solar utilization. The third study, currently in progress, examines the robustness of two policies (a supply and a demand policy) and their effect on the penetration of renewable technologies across a range of reference cases designed to capture several of the uncertainties faced by dectsion makers. 
THIS PAGE

\section{WAS INTENTIONALLY \\ LEFT BLANK}


CONTENTS

Abstract

I. Introduction $\ldots \ldots \ldots \ldots \ldots \ldots \ldots \ldots \ldots \ldots \ldots \ldots \ldots \ldots \ldots \ldots \ldots \ldots \ldots \ldots \ldots \ldots \ldots \ldots$

II. Description of Modeling System ...................... 1

A. Econometric Model Description ................... 1

B. Process Model Description ......................... 2

C. Input-Output Model Description ................... 4

D. Model Integration Description ................... 5

III. Rationale For Integrated Approach .................. 6

A. Individual Model Advantages and Disadvantages ....... 6

B. Benefits of Integration ........................ 8

IV. Sectoral Classifications, General Structure, and Solution Procedures for the Models ........................... 9

A. Sectoral Classification ....................... 9

B. General structure .............................. 9

C. Solution Procedure ........................... 9

V. Data Sources and General Availability ................. 15

A. Data Sources ................................ 15

B. General Availability ........................ 15

VI. Planned Improvements ............................ 16

A. Econometric Model ........................... 16

B. Process Model ................................ 16

C. Input-0utput Model .......................... 16

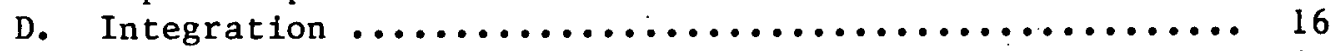

E. Demand Extensions ........................... 17

VII. Model Appitications ............................. 18

A. General .................................... 18

B. Specific Studies ............................. 21

VIII. Conservation Policy Analysis ........................ 22

A. Conservation and Growth ......................... 22

B. Economic Implications of Increased Solar Usage ....... 23

C. Renewable Technologies ......................... 25

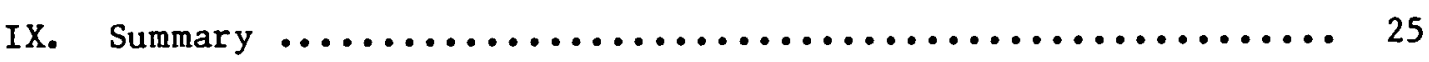

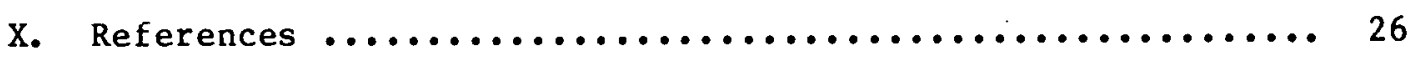


IV. 1 Sectoral Configuration of the Input-Output Model ........ 11

VI. 1 Status Report of BNL Industrial Process Optimization Modeling ..................................... 19

VII. 1 Models and Applications ........................ 21

\section{FIGURES}

IV. 1 Sectoral Classification and Interindustry Transactions in the Econometric Model (LITM) ...................... 10

IV. 2 Sectoral Classification and Energy Flows in the Process Model (TESOM) ............................... 10

IV. 3 Economic Flows In LITM $\ldots \ldots \ldots \ldots \ldots \ldots \ldots \ldots \ldots \ldots \ldots \ldots \ldots \ldots$

IV. 4 Reference Energy System $\ldots \ldots \ldots \ldots \ldots \ldots \ldots \ldots \ldots \ldots \ldots \ldots \ldots$

IV. 5 Interindustry Transactions in the BNL/IIlinots Input - Output Model $\ldots \ldots \ldots \ldots \ldots \ldots \ldots \ldots \ldots \ldots \ldots \ldots \ldots \ldots \ldots$

IV.6 BNL/DJA Combined Model system .................. 14 


\section{INTRODUCTION}

The methodology used by Brookhaven National. Laboratory to analyze alternative energy policies and their impacts on the energy and economic systems of the United States involves the integration of three different models. A long-run macroeconomic growth and interindustry model, econometric in nature, is used to estimate the aggregate energy/economy interactions and the long-run path of the economy. A linear programming, process-type model is used to estimate the least-cost method of meeting specified energy service demands, and it captures the substitution possibilities within the energy system. A disaggregate input-output model is used to assess the impacts of the aggregate energy/economy interactions on detailed industrial sectors.

\section{DESCRIPTION OF MODELING SYSTEM}

\section{A. Econometric Model Description}

The econometric model is the Dale W. Jorgenson Assoctates (D JA) Longterm Interindustry Transactions Model (LITM). The DJA model simulates the structure and growth of the U.S. economy. Economic activity is estimated on a sectoral basis: six energy and four nonenergy sectors. Explicitly taken into account are the dynamic and interdependent structures of prices, inputs, and final demands. The sectors are brought into consistency through a flexible coefficient interindustry representation of sectoral production. The production capacity of the economy over time is modeled by explicit incorporation of productivity trends, investment, and labor supply. The emphasis is on the energy system and its role in the economy in relation to both production and consumption. The model provides a consistent framework for analyzing the effects of economic changes on the energy system and the effects of energy changes on the structure and growth of the U.S. economy. The interrelationships are estimated econometrically from a 1947 to 1972 data base. (Jorgenson and Hudson, 1974 and 1977.) 


\section{B. Process Model Description}

The Time-stepped Energy System Optimization Model (TESOM) is a national energy system model based on Brookhaven's Reference Energy System (RES). The RES provides a complete and consistent accounting system, in physical units, for energy flows and for capital stocks of energy-producing and-consuming technologies. With appropriate conversion efficiencies, the RES proceeds from the extraction or importation of primary energy resources and products, through refining and the various stages of energy conversion, transportation, distribution, and storage, to the consumption of fuels and electricity by end-use technologles corresponding to a particular energy service demand. Within the RES, emphasis is placed on a comprehensive technological structure relating the energy flows which enter the system (o1l, gas, coal, uranium, solar, etc.) to the relatively nonsubstitutable, functional energy services which are the final product of the flow (space conditloning, motive power, process heat, lighting, etc). Thus, the RES framework reflects the full, feasible range of interfuel and technological substitutability.

The time-stepped model optimally allocates energy resources and products and selects the least-cost mix of supp1y, conversion, and demand technologies to satisfy a specified set of energy service demands. Resource supply representations are specified as supply curves for each period, resource avallability curves over all time periods, or fixed prices and avaflabilities by year. The TESOM model provides a "vintage" representation of the nation's energy system in that the optimal levels of the decision variables for any time period are determined from the optimal levels established for previous periods; the retirement and deterioration rates, the lifetimes, and the associated costs of vintage capital stocks; and economic and téchnólogical factors affecting the feasible levels of the decision variables for the period under investigation.

Mathematically, the model is formulated as a sequence of linear programming formulations of the RES--one for each time period. For a given time period, the solutions derived for earlier periods along with assumptions regarding retirement and decline rates, average lifetimes, 
age-dependent conversion efficiencles, plant factors, O\&M costs, and the capital charges for the stocks-in-place are incorporated into the sequenced formulation. Then, at least cost, the energy demands are satisfied in accordance with the supply expansions and increased penetrations that are attainable for the period and the net avallabilities from the evolution of the energy system to date. In meeting future energy demands, TESOM has a memory of the net availabilities from the past augmented by that which is attainable in the near term. The updating and sequencing procedures are repeated until solutions for the entire time horizon are determined.

As with other BNL energy models, IESOM provides a unique representation of electricity generation. A set of demand types (e.g., base and intermediate loads, off-peak, heating, cooling, etc.) are defined. Each demand type has its own set of characteristics regarding its stochastic behavior and its seasonal and daily loading. Required capacity is governed by the highest total peak demand which occurs during some time of the year and day. By appropriately loading the electric energy service demands onto the various demand types and, subsequently, loading these onto the various season-day combinations, the height of the total peak for each season-day is determined. Required capacity is simply the maximum of the individual season-day peaks with allowances for transmisston and distribution losses and reserve margins. Thus, the load duration curve is, in part, determined from the exogenous detailed demand characteristics.

The model contains a number of features designed to smooth the intertemporal transitions. A mechanism for pricing and adjusting the availabilities of vintage stocks and a market penetration algorithm are incorporated as a means of avoiding the bang-bang characteristic of linear programing models. To the extent that the age of a vintage stock is not beyond its economic lifetime, the annualized capital charges for the technology impose a cost on the system. Thus, the fixed costs associated with previous investments are incurred irrespective of whether or not it is optimal to operate, partially or fully, an older technology. 
The procedure for market penetration requires, as input, optimistic penetration levels for each technology in each year. The penetration algorithm then incorporates the marginal values, implementation rates, and lag times from previous periods as well as the technological and market characteristics for the current period into the determination of realistic bounds for the activity levels. The user specifled bounds are adjusted endogenously to account for the previous penetration and attractiveness of the technology. (Cherniavsky, 1974; Kydes, 1978; and Kydes and Rabinowitz, to be published.)

C. Input-Output Model Description

Several distinguishing characteristics of the BNL Inpul-uulpul mudel differentiate it from conventional interindustry input-output models. First, the BNL model contains energy sectors whose output is expressed in physical units (Btu) instead of dollar values. Second, outputs of the energy supply/conversion sectors are distributed to energy service sectors instead of directly to consuming sectors. The supply sectors convert and distribute raw fuels to sectors producing traditional energy forms (e.g., electricity and refined petroleum products), but they allow for nontraditional patterns (e.g., refined petroleum products from coal). The outputs of these energy supply/conversion sectors are then distributed to dummy energy product or service sectors.

This structure allows for the specification of transactions in terms of end uses. The dummy energy product sectors define end-use demands for energy exhibiting a limited degree of substitutability: motive power, petrochemical feedstocks, coke, process heat, water heat, space heat, air' conditioning, and electric power.

The interindustry structure of the input-output transactions matrix permits detailed sectoral analysis within the context of the national economy. The input-output accounting system is particularly useful in bridging the gap between the microstructure of each of the sectors and aggregates such as GNP and personal consumption expenditures. (Knect and Bullard, 1975; Behling and Dennehy, 1975; Knect, 1975; Lukachinski and Tessmer, 1976; and (Tessmer et a1., 1977.) 


\section{Model Integration Description}

The integration of these models takes place at two levels. The first integration is between the econometric model and the process model. The second integration uses the solution to the first coupling to provide the final demand and energy sector detall necessary to drive the input-output model.

The process model (TESOM) allocates energy supply so as to satisfy a set of demands for energy services. The level and structure of the energy demands incorporate the economic conditions generated by the econometric model (LITM). The model coupling operates through several stages. Inttially, average energy supply prices are calculated in TESOM. Use of demand price elasticities yield estimates of primary energy consumption and corresponding energy service demand levels. (The elasticities summarize results of previous runs of the TESOM/LITM system.) TESOM is then solved, subject to providing these quantities of energy services. The solution values of energy prices, capital requirements, quantities, imports, and levels of new energy technologies are entered into LITM which is then solved, yielding specific estimates of the level and composition of production and spending throughout the economy. Economic sector outputs, and the energy input per unit of output, are mapped into a set of demands for energy services, specified in British thermal units. Next, these energy service demands are adjusted to incorporate the effects of any efficiency improvements in energy end-use devices. At this point, the energy demand vector reflects changes in energy prices, the level and composition of spending in the economy, energy and nonenergy input substitutions in production, and end-use device efficiencies. These energy demands are inserted in TESOM and, along with the policy specific price assumptions, yleld a second-round simulation of the configuration of the energy system. The iteration procedure then continues unt1l consistency between the energy and economic systems in the two models is attained.

Once a consistent TESOM/LITM solution is achieved, the input-output model is run. The aggregate nonenergy final demands from LITM are used 
as control totals for the nonenergy final demands in the input-output model. The energy final demands in the form of energy services are provided by TESOM. In addition, the technical coefficients representing the energy supply to energy product conversions are derived from the TESOM/ LITM solution. This allows for the incorporation of energy supply substitutions resulting from specific policies in the input-output model. At this time, the nonenergy coefficients are fixed and are not policy dependent. Solution of the input-output model yields the detailed output requirements of the economy. (Behling et al., 1975; Tessmer et al., 1975; Tessmer and Sanborn, 1975; Behling and Du111en, 1976; Hoffman and Jorgenson, 1977; and Fraser, 1978.)

\section{RAT IONALE FOR INTEGRATED APPROACH}

\section{A. Individual Model Advantages and Disadvantages}

1. Econometric Model. The original formulation of LITM was undertaken for the Ford Energy Policy Project. At that time, before the 1973 oil embargo, the model was used to show the long-run effects on the U.S. economy of two energy-conserving futures: a technical fix scenario and a zero economic growth scenario. The model projected large reductions in energy use with much smaller relative reductions in economic output. This contradicted the conventional wisdom in 1973 and was challenged on it's lack of technological content. Like all econometric models, it represented technological change through implicit elasticities but did not specifically identify or describe the technologles.

A strength of the LITM model is that the composition of final demand and the factor $\mathrm{mix}$ for each energy and nonenergy sector are functions of factor prices. Unlike all earlier and most later models, this price responsive representation of input-output relationships is more realistic than projections of constant input-output relationships. (Energy Policy Project, 1974; Jorgenson and Hudson, 1974; and Charles River Associates, 1977.) 
2. Process Mode1. Energy demands for the process models are generated by projecting the level of energy services. The model solutions respond to higher energy prices by introducting more energy-effictent, higher capital cost technologies, and by shifting the fuel mix to lower priced fuels, but the service demands remain unchanged. Hence, demand responses are only partially captured, and the implicit demand elasticities are too small. An additional weakness of the process models is that the solutions can flip-flop with closely competing technologles either totally chosen or rejected.

On the positive side, the process model presents each technology in engineering detail. This has proved useful in improving communication between economists and engineers. Sensitivity analyses of uncertain costs or constraints are easily performed with available software packages. The normative model solutions are useful in indicating socially beneficial policy initiatives where imperfections would tend to foreclose the adoption of efficient technology options. The solutions generate shadow prices, and their magnitudes are extremely useful as a measure of sensitivity. (Charles River Associates, 1977.)

3. Input-Output Model. Typical input-output models incorporate historical base year coefficients. These fixed coefficients do not reflect the changing composition of sectoral output due to changing relative prices or the scale effect of different output levels as capital equipment of different vintages is phased in or out. In addition, the tables are dated since half a decade or more usually passes between the collection of the data aud the publication of the coefficients. Although schemes exist to project coefficients, projections still suffer from the scale, vintage, and sector mix weaknesses. Input-output models do not include coefficients for new technologies, nor can the coefficients change in response to relative price changes.

The Brookhaven-Illinois version of the Department of Commerce 1967 input-output tables was developed to ameliorate some of these problems for energy studies. First, new technologies are introduced by estimating input-output coefficients and adding appropriate rows and 
columns. Second, intermediate and final energy demands are respecified in terms of energy services and dummy sectors are added for these services. Thirdly, the energy supply and energy service sectors are defined in physical units. This permits direct linkage with the energy process model and provides variable energy coefficients, determined by the solution of the process model. Finally, the nonenergy coefficients are projected for future years. This input-output approach provides a consistent accounting framework that $c$ an be used to trace the system-wide effects of energy policy initiatives or changes in final demand in a comprehensive and systematic manner. (Charles River Associates, 1977; Just et a1., 1975; and Fraser, 1978.)

B. Beutilts of Integration

The weaknesses associated with each of the above models were recognized by the model builders. In 1973, an effort was begun at Brookhaven to link the energy sectors of the Illinois input-output model to the Brookhaven process model. At the same time the MITRE Corporation estimated input-output coefficients for advanced energy technologies. This coupling, completed in 1975, enabled one, to estimate the output, employment, balance of payment, and capital requirement effects of various energy policies and advanced technology options across ninety nonenergy sertors. To a large extent this model was able to answer the net energy questions that were being ralsed at the time.

In 1975, as a result of criticism of the Ford Policy Model for its lack of technological detall and of the process model for.its lack of price elasticities and energy-ecunumy iuteractions, a program of model linkage was initiated. Energy demands for the process model were derived from the econometric model solution. The econometric model was constrained by the technologically determined prices, capital requirements, and fuel mix from the process model. Still later, it was used to provide control totals for the nonenergy sectors of the already linked process $I-0$ models. Work is currently under way to reflect in the $I-0$ model the variable coefficient information from the econometric model, including adjustment of the labor and capital value added coefficients. The 
benefit of these integrating activities has been to strengthen each model by directly attacking its weaknesses with the strength of a complementary model.

The weakness associated with the national dimension of a U.S. energy model remains, although the process model solution can be disaggregated by a regional version. Finally, neither the supply sectors nor the international impacts are fully modeled, and their treatment is exogeneous to the model structure.

IV. SECTORAL CLASSIFICATIONS, GENERAL STRUCTURE, AND SOLUTION PROCEDURES FOR THE MODELS

\section{A. Sectoral C1assification}

All of the models are currently run at the national level for the United States. However, each model has different levels of industrial and technological detail. The sectoral configurations for LITM, TESOM, and the input-output model are presented in Figures IV. 1 and IV. 2, and in Table IV.1, respectively.

B. General Structure

Figure IV. 1 also presents a general picture of the interindustry portion of the Hudson-Jorgenson Model (LITM), and Figure IV. 3 shows the economic flows in the model. Figure IV. 4 is a Reference Energy System which represents in a simplified fashion the interactions and flows of the process model (TESOM). The transactions formulation of the input-output model is presented in Figure IV. 5.

C. Solution Procedure

LITM and TESOM are coupled so that, in each year, there is consistency between the energy and economic information obtainable from each model. This coupling is achieved through an iterative process in which the principal points of Inleracliun are:

- The economic activities (outputs) of each sector and the aggregate energy inputs to the producing sectors, the household sector, and other final demand activities. 
- Industry Sectors:

1. AgRICULTURE, NONFUEL MINING, AND CONSTRUCTION.

2. MaNufacturing, EXCLUDING PETROLEUM REFINING.

3. TRANSPORTATION

4. Communications, trade, AND SERVICES.

5. COAL MINING.

6. Crude Petroleum.

7. Natural Gas.

8. Petroleum Refining.

9. ELECTRIC UTILITIES.

10. GAS UTILITIES.

- Primary inputs:

11. IMPORTS.

12. Capital Services.

13. Labor Services.

- final Demands:

14. PERSONAL CONSUMPTION EXPENDITUREE.

15. Gross Private Domestic INVESTMENT .

16. GOVERnMent Purchases

17. EXPORTS.
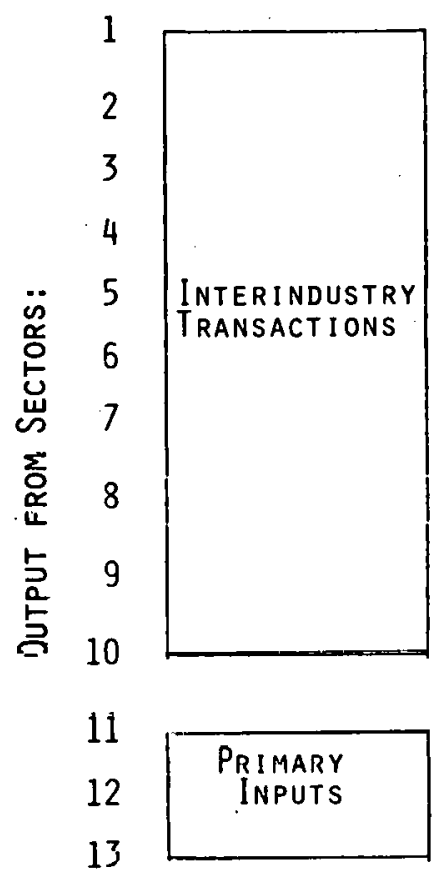

Total Inputs

F1gure IV.1. Sectoral classification and interindustry transactions in the econometric model (LITM).

- ENERGY RESOURCE CATEgORIES:

ENERGY RESOURCE CATEGORIES

1. UNDERGROUND COAL.

2. STRIP-MINED COAL.

3. DOMESTIC OIL.

4. SHALE OIL.

5. IMPORTED OIL.

6. DOMEJTIC NATURAL SAS.

7. IMPORTED NATURAL GAS.

8. HYDRO ENERGY.

9. NUCLEAR ENERGY.

10. GEOTHERMAL ENERGY.

11. SOLAR ENERGY.

- ENERGY SERVICE CATEGORIES:

12. BASE LOAD MISCELLANEOUS ELECTRIC.

13. INTERMEDIATE LOAD MISCELLANEOUS ELECTRIC.

14. PEAK LOAD MISCELLANEOUS ELECTRIC.

15. STORAGE AND SYNTHETIC FUEL.

16. MISCELLANEOUS THERMAL, LOW TEMPERATURE.

17. MISCELLANEOUS THERMAL, INTERMEDIATE TEMPERATURE -

18. MISCELLANEOUS THERMAL, HIGH TEMPERATURE.

19. ORE REDUCTION (IRON).

20. PETROCHEMICALS .

21. SPACE HEAT.

22. AIR. CONDITIONING.

23. WATER HEAT.

24. AIR TRANSPÜRT.

25. TRUCK, BUS.

26. RAIL.

27. AUTOMOBILE.

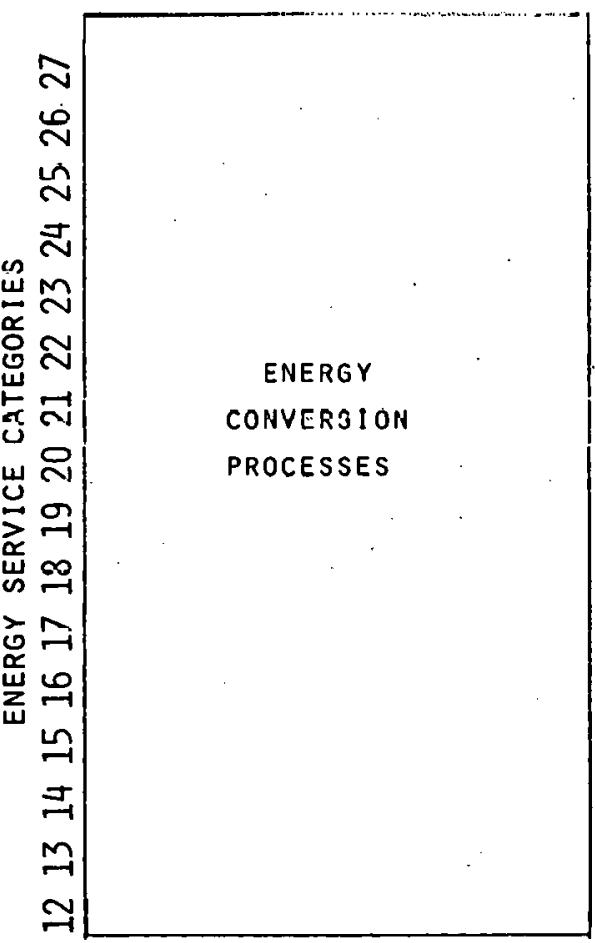

Figure IV.2. Sectoral classification and energy flows in the process model (TESOM). 
Table IV.1

Sectoral Configuration of the Input-Output Model

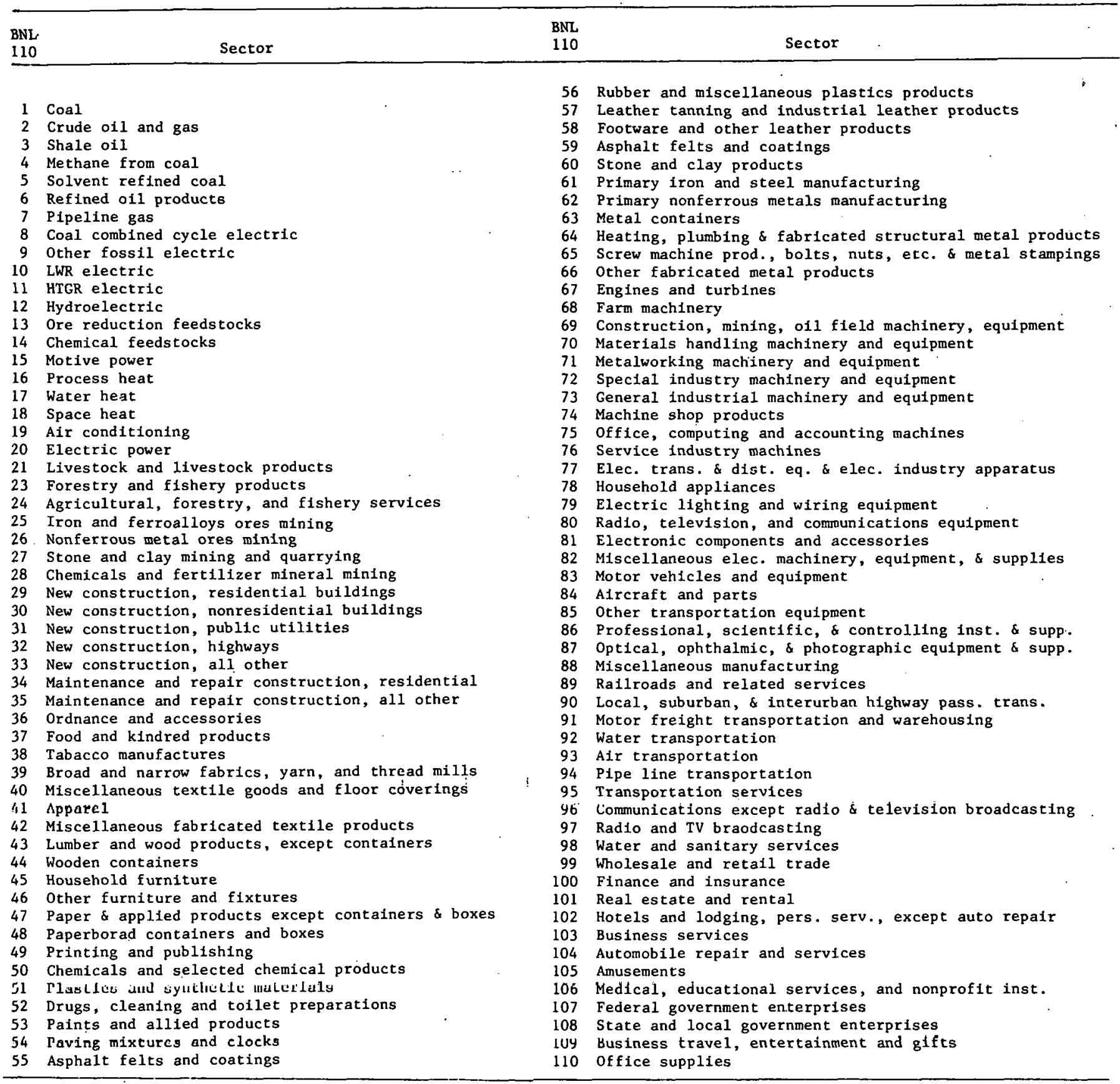




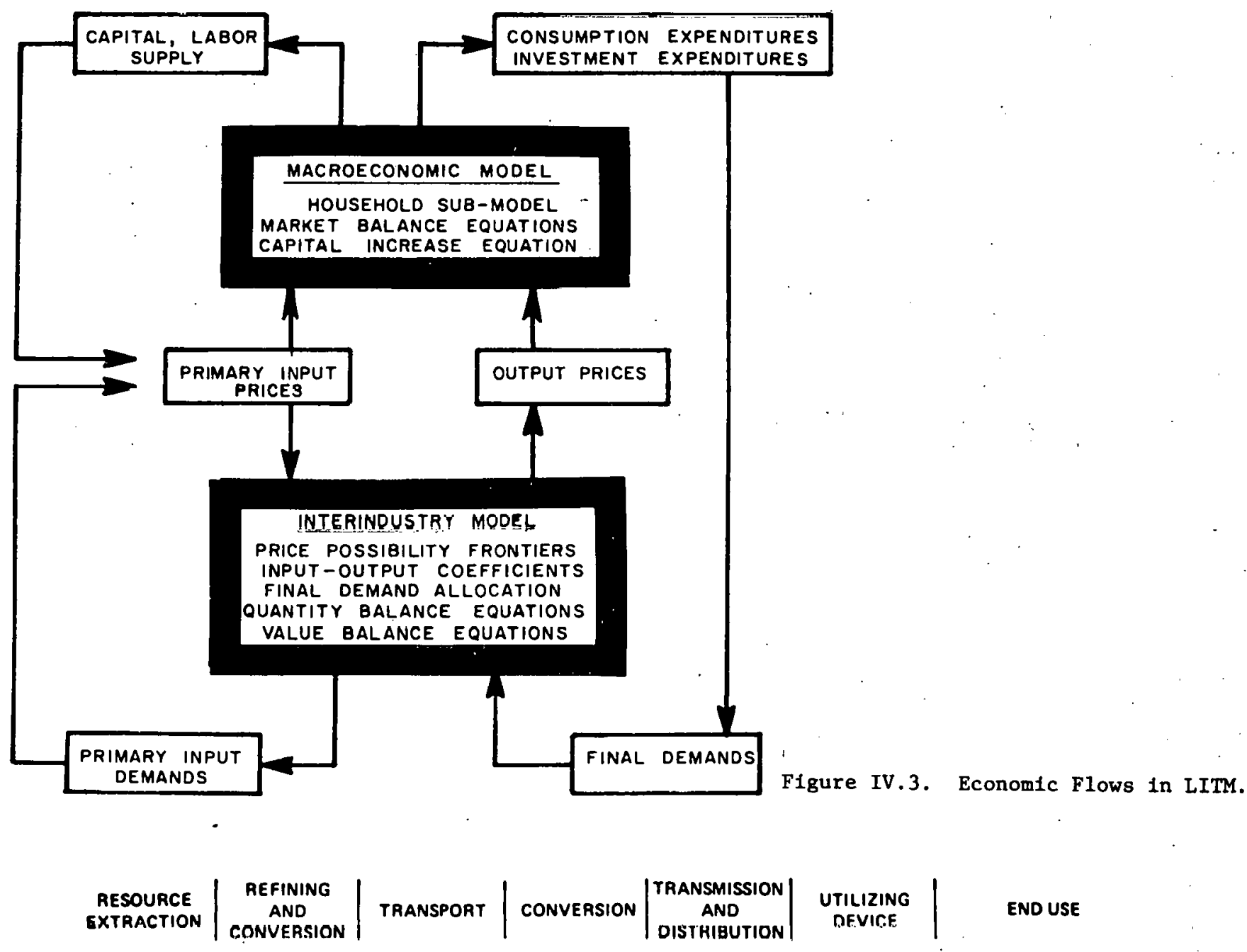

NUCLEAR

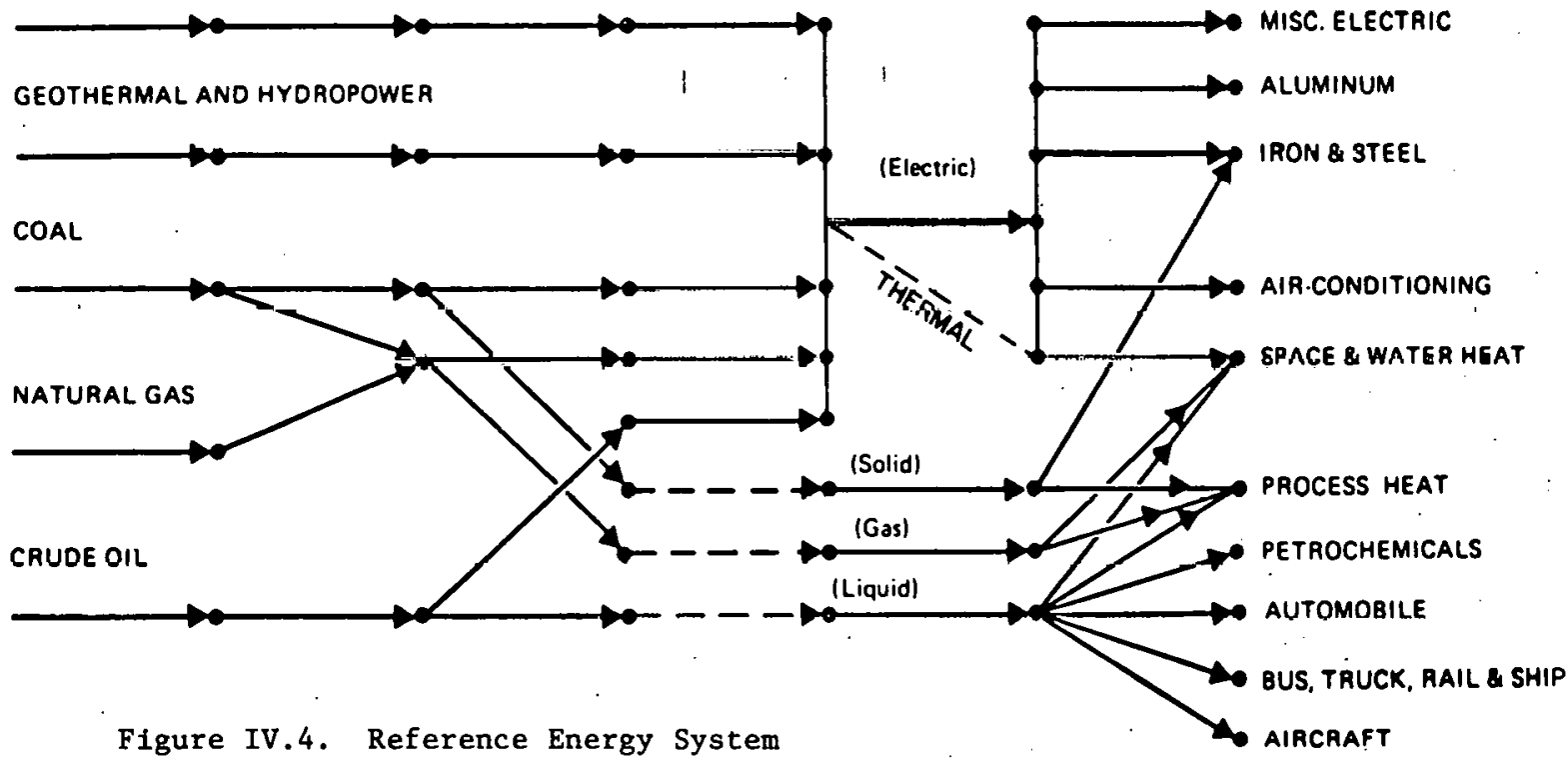




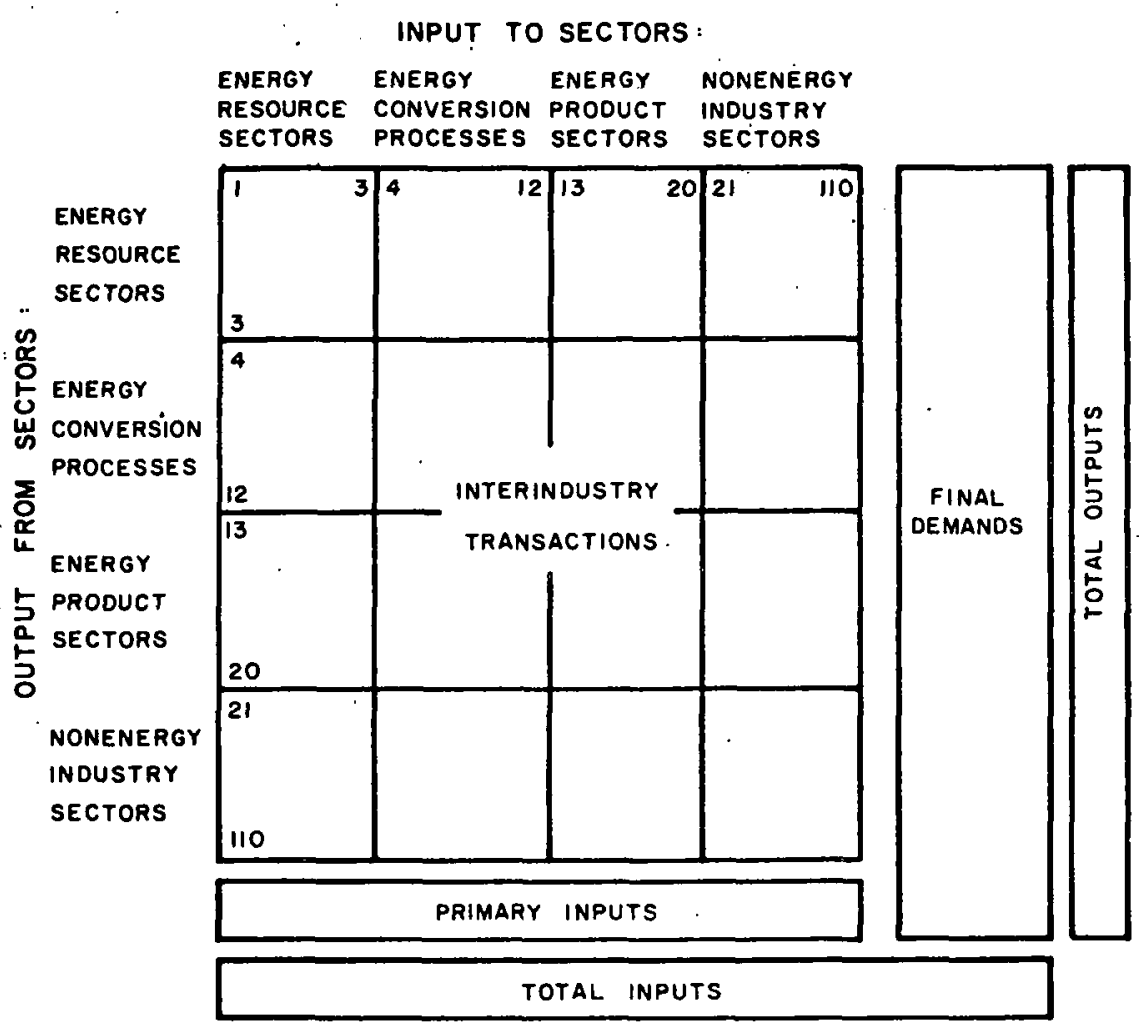

Figure IV.5. Interindustry Transactions in the BNL/I11inois Input-Output Model.

- The relationship between the aggregate energy inputs to the producing and consuming sectors and the levels of the nonsubstitutable, functional energy services.

- The details of energy prices, capital requirements, quantities, imports, and the levels of new and conventional energy technologies.

- The relationships among the energy sector details, aggregate energy and nonenergy input substitutions, product substitutions and compositional changes in final demand, and the growth of the economy from both demand and supply points of view.

Once consistency is reached between LITM and TESOM, the input-output model is solved using the aggregate economic flows of LITM as control totals and the energy demands and energy product coefficients from TESOM. The interactions of the combined model system are presented in Figure IV.6. 


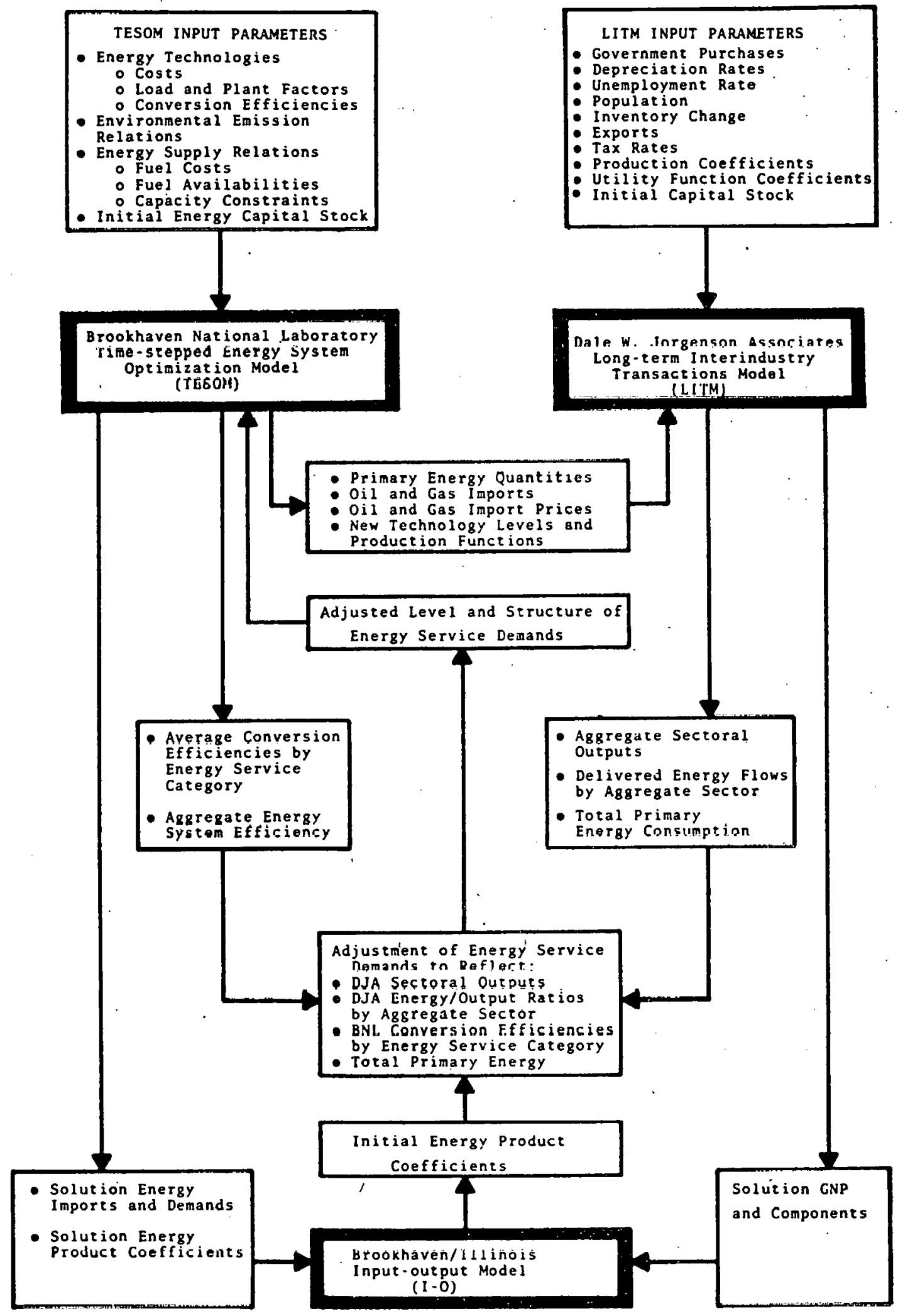

Figure IV.6. BNL/DJA Combined Model System 


\section{DATA SOURCES AND GENERAL AVAILABILITY}

\section{A. Data Sources}

1. Econometric Mode1. The data underlying the specification of the translog production frontier are derived from a data base prepared for the Ford Policy Studies. These data are sectoral output quantities for the United States for the period 1948-1972. The estimated parameters of the translog function establish the variable coefficients in the interindustry model. The macroeconomic model rests on work prepared by Christensen and Jorgenson, who documented the underlying data in a series of articles. (Faucett, 1973; and Christensen and Jorgenson 1969, 1970, $1973 a, 1973 b$.

2. Process Model. The original data base for the process model was derived from a wide range of sources and has been documented by Beller. This data base, known as the Energy Model Data Base, is continually updated and is maintained at Brookhaven National Laboratory. (Beller, 1975; and Goldberg et al., 1976.)

3. Input-Output Model. The input-output nonenergy coefficients are projections of the Department of Commerce 1967 interindustry coefficients to 1985 and 2000. They are, in part, based upon projections made by the U.S. Department of Labor. The energy process to nonenergy sector coefficients were derived by Brookhaven and the University of Illinois from the Stanford Research Institute's pioneering work on generating energy service quantities from sectoral fuel use data. Data for new technologies were developed by the MITRE Corporation. (Bureau of Economic Analysis, 1975; Stanford Research Institute, 1972; Behling and Dennehy, 1975; Knect and Bullard, 1975; Just et al., 1975; Lukachinski and Tessmer, 1976; Goldberg et al., 1976; U.S. Department of Labor.)

B. General Availability

The latest version of the econometric model is proprietary and is the property of Dale W. Jorgenson Associates. The model is available for use in studies contracted with DJA. The process model, the input-output 
model, and the combined version were developed under U.S. Government funding and are in the public domain. However, Brookhaven National Laboratory is not funded to provide transfer services or to make model runs not covered by currently funded programs.

\section{PLANNED IMPROVEMENTS}

\section{A. Econometric Model}

The econometric model is being expanded from ten to thirty-six producing sectors with several refinements and an extension of the data base. Also, a detalled model of consumer expenditures is being developed and will become an integral part of the system. (Jorgenson et al.. 1975; and Hudson et al., 1978.)

\section{B. Process Mode1}

Minimization of the cost of meeting a specified set of energy demands is not the sole objective of energy policy. Therefore, work has been progressing on a multiobjective formulation of BESOM (and, eventualiy, of TESOM) to take into account other objectives including minimization of environmental impacts, of imports, and of capital costs. (Cherniavsky et al., 1977; Kydes, 1978; and Schank, 1978.)

C. Input-Outpul Mude1

The Input-output model will be updated from a 1967 base with availability of the 1972 input-output tables from the U.S: Department of Commerce. In addition, the energy flow coefficients will be updated to 19/2. (Bureau of Economic Analysis, 1979.)

\section{Integration}

An integrated multiregional energy and interindustry model of the U.S. has been developed, but not yet implemented, by Brookhaven National Laboratory. The energy sector of this formulation is represented in a detailed multiregional linear programing model. This model optimally allocates regionally produced energy resources and selects the optimal regional mix of energy supply, conversion, and demand technologies 
according to least cost or other important criteria to meet projected regional energy demands. Regions are linked by both imports and exports of natural resources and converted fuels or products, including electricity. Resources are characterized by region-specific supply functions, and regional energy demands are speciffed in terms of functional end uses (e.g., space heat, air conditioning, process heat, motive power).

The energy sector model is integrated with a multireglonal Leontief interindustry model of the economic system. Here, regions are linked not only by interregional energy flows but also by interregional industrial flows. The traditional components of final demand result from macroeconomic projections of regional product and its. composition and may be derived from a typical multiregional econometric model.

A methodology has also been developed to more fully integrate the disaggregate input-output model with the more aggregate econometric model. This methodology will guarantee the consistency between the disaggregate technical coefficients, outputs, and relative prices of the input-output model and their counterparts in LITM. The effect of this integration will be to incorporate the general equilibrium adjustments occurring in LITM into the input-output model.

Work is also being done on the incorporation, in a hierarchical framework, of more detailed environmental effects models with the energy and energy/economy models discussed herein. (Goettle et al., 1977; and Groncki, 1978.)

\section{E. Demand Extensions}

1. Energy Use in Buildings. Parailel to the energy/economy model development and application activity is one directed to energy demands. A detafled engineering process-type model has been developed for residential and commercial buildings. This model may be operated independently or coupled to TESOM where it replaces the aggregated description of residential and commerçial building energy demand with a highly disaggregated version. It has been used with the input-output model to study the 
sectoral effects on employment and output of various energy conservation initiatives. (Marcuse et al., 1976; Carhart et al., 1978; and Tessmer et a1., 1978).

2. Energy Use in Industry. In order to understand the impact on industrial energy use, a set of disaggregated engineering process models of major energy using industries is under development. These models are driven by prices and industry output growth rates from the combined models. At present, the capital requirements generated by the industry models and the implicit product prices are not fed back to the more aggregated models. Long-run plans include marrying the disaggregate industry process models directly to the aggregated ones. One approach is to use a hierarchical structure embodying two-way flows of output information between the aggregated and disaggregated models and iterating to convergence. This could even be formalized into a single model that would be solved by decomposition techniques. The alternative approach is to run each process model across a wide range of price and demand quantities, and fit the results to some mathematical function. Results from the aggregated models would be fed into the reduced form function as independent yariables. The dependent variables generated would be fed back to the higher level aggregated functions. Table VI.l indicates the current status of the industry process models. (P1lati and Rosen, 1978a; Marcuse et al., 1978; Pilati and Rosen, 1978b; Marcuse et al., 1979; Coward and Sparrow, to be published; and Sparrow, to be published.)

3. Energy Use in Transportation. Plans are currently being made to include disaggregated models of the transportation sector in the overall framework. However, no work has been initiated to date.

\section{HODEL AFRLICATIONG}

\section{A. General}

1. Technology Assessment. The TESOM module contains engineering process characterizations of supply and end-use energy conversion technologles. Future technologies are described in terms of their 


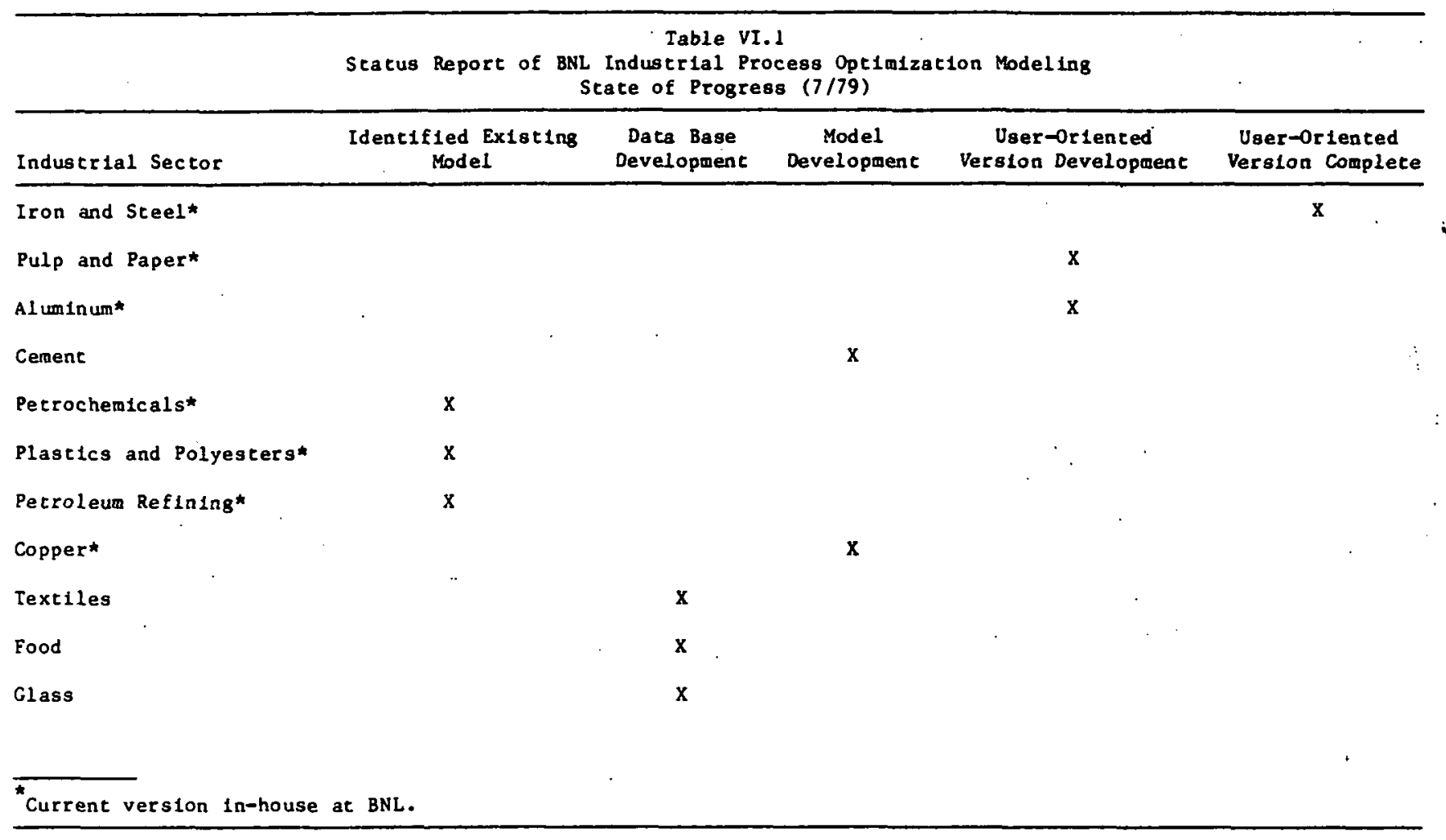

availability dates, efficiencies, costs, and market penetration characteristics. Each competes with existing and future technical alternatives. By changing availability dates or costs and efficiencies to represent differing technical outcomes reflecting the level of R\&D support or uncertainty, the role of each technology can be identified: By eliminating selected technical alternatives, the impact upon the implementation of others can be indicated. By changing efficiencies or costs, comparisons can be made reflecting optimistic and pessimistic R\&D outcomes. Finally, policy alternatives can be studied that accelerate or delay (perhaps preclude), or that subsidize or penalize specific technologies.

2. Tax and Incentive Policies. The DJA model was originally formulated to examine energy futures using prices to effectuate policy goals. It is an ideal vehicle for examining energy tax and subsidy policies, either across the board or for specific fuels. The response of the economy to the adjusted energy prices is fed into the TESOM model which then identifies the specific technological response to the new relative price structure. The TESOM model is particularly useful in identifying the 
response to tax credit and subsidy policies for specific technologies. TESOM can be used to reflect the impact of regulations and standards by specifying the performance level of technical alternatives. For example, automobile standards of 27.5 miles per gallon in 1985 are entered directly by characterizing a vehicle with the mandated performance and forcing it into the solution.

3. Markets. The models can be used to Investigate the impact of policy actions upon specific market sectors. One application has been to ask what the response of the economy and the energy system would be to a program specifically directed to a given level of solar market penetration. Shadow prices on higher cost technologies are brought in to the model solution with equality constraints. They indicate where and at what level incentives or subsidies will be needed. Feedback effects upon the economy are also identified. Linkages to the input-output model indicate changes in skill $\mathrm{mix}$ and sectoral growth or decline. Both the input-output model and the DJA model generate changes in labor productivity.

4. Resources. The model framework does not endogenously generate resource supply curves. The DJA model is heing linked to coal, oil, and natural gas supply models. However, the TESOM structure accepts exogenously determined supply functions (of several possible formulations) and LITM also requires inputs representative of resnurce availabilitios and costs. Alternative future resource scenarios can be studied by modifying these inputs. Some examples are:

a. Limited uranium supplies.

b. Quantity limits on imported oil.

c. Optimistic natural gas futures.

d. Higher coal costs based upon:

i. increased extraotion costa due to enivilunmenlal or safecy regulations;

11. increased supply costs if elther coal companies or labor unions capture economic rents;

1ii. decreased availability reflecting regulations permitting only very low-sulfur coal to be used.

e. Limitation on coal to prevent atmoopheric $\mathrm{CO}_{2}$ buildup.

f. Limitation of synthetic fuel production reflecting water scarcity. 
g. Limitation on nuclear reflecting moritoria legislation.

h. Capital stock limitations reflecting delays in pipeline construction or licensing.

B. Specific Studies

Table VII. 1 gives a partial list of studies performed using various combinations of the models. The evolution of the modeling structure is clear. Neither the process model alone nor in combination with the inputoutput model is cited after 1977. The completed linkage of the econometric and process models has been the major tool since 1976. The linkage of all three was first applied in 1977 although more development work is needed before this linkage will be complete. The econometric model will continue to be exercised independently of the energy process links for addressing certain types of questions.

The range of application is wide with most studies addressing energy conversion and end use. This is not surprising as the general economywide effects are not self-evident, and partial analyses distort both the formulation and assessment of policy initiatives.

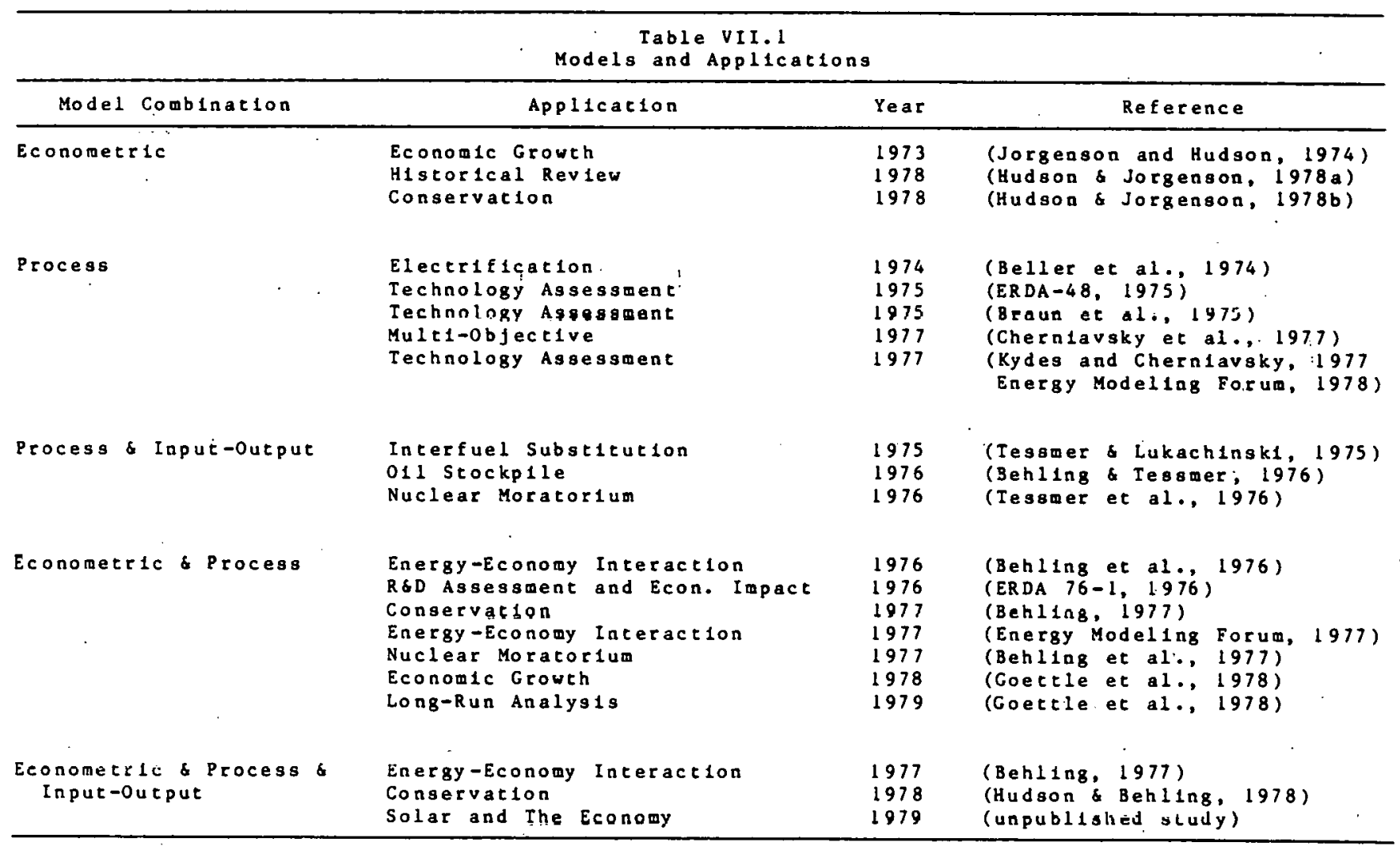




\section{CONSERVATION POLICY ANALYSIS}

\section{A. Conservation and Growth}

In a major study conducted in 1977, the possibilities for, and the consequences of, slowing the rate of increase in U.S. energy consumption over the remainder of this century were examined. Four packages of energy policles incorporating various combinations of taxes, subsidies, tariffs, and direct regulations were examined. These packages were structured in order of increasing severity. If implemented, they would yield successive reductions in the rate of growth of energy use, with the most severe package leading to zero energy growth. The effect of the policies on the development of the energy system was investigated with particular attention given to changes in the fuel mix, the degree of electrification, and the volume of energy imports. The effects of such policy-induced energy changes on the economy were also analyzed. The focus was on the reduction in the level of economic activity that would accompany the reductions in energy input. The more detalled aspects of changes in the economic structure caused by the energy policles were examined, along with the processes and mechanisms which relate changes in energy consumption to changes in the level and pattern of economic activity.

The first two policies were designed to represent possible conservation-oriented government energy policies. The third and fourth policies were included primarily for analytical purposes, in that, unlike the first two policies, they are not currently being considered for actual adoption. These policies introduce energy taxes sufficient to limit primary energy input to 90 and 70 quads in 2000, respectively. There is always a danger of exceeding the "span" of a model when it is employed to examine extreme cases. Hence, the 90- and 70-quad results must be viewed with this caveat in mind.

Analysis of each of the four energy policy packages suggested that substantial reductions in the volume of energy use, relative to the reference case, could be achieved with far less than proportionate 
reductions in economic activity. This nonproportionality results from adjustments in the pattern of energy use and in the structure of economic activity.

This flexibility in the energy-economy relationship is highly significant. From a policy point of view it suggests that it is possible to implement long-run energy policies designed to restrict energy growth without having to suffer comparably large economic costs in terms of reduced GNP and slower economic growth. This makes it possible to contemplate restrictive energy policies, e.g., policies designed to reduce petroleum imports. There is still an economic cost, but it is possible that policymakers would judge this cost to be small compared to the benefits obtained from attaining the energy objectives. From a forecasting point of view, this result provides important information for assessing the likely economic impacts of increases in energy prices, whether due to government policy, increasing relative scarcity of resources, or external influences. The ability to make meaningful and reliable projections is important for planning in both government and private sectors. (Hudson and Behling, 1978.)

B. Economic Implications of Increased Solar Usage

In early 1979, Brookhaven National Laboratory and Dale W. Jorgenson Associates conducted a study for the Solar Energy Research Institute which examined the economic impacts of increased solar utilization. This study, although of a preliminary nature, made use of the econometric, process, and input-output models and yielded some broad conclusions with policy implications. The Base and Maximum Practical solar penetration levels determined by the Domestic Policy Review for 1985 and 2000 were used as guidelines.

The accelerated introduction of solar energy has both short- and longrun consequences. In the short-run, GNP, employment, productivity, and the balance of trade could all be affected. These short-run adjustments have implications for the long-run trends of inflation and economic growth. The actual effects will depend on whether the economy is in a 
state of excess or full capacity and whether the costs (both construction and life cycle) are greater or less than those of conventional energy.

For this study, it was assumed that the economy would operate at full capacity. Three Maximum Practical cases were examined relative to a Base Case with minimal solar penetration levels. Two of these cases assumed that solar energy was more expensive than conventional energy, in both capital and life-cycle costs. In one case, the consumers of energy pay this cost difference (User Pays Case), while in the other, the government subsidizes consumers for the difference (Subsidy Case). In the third case, it was assumed that solar energy life-cycle cost was not more expensive than conventional energy (Competitive Case). However, the Competitive Case did assume that the structure of the costs would be different for solar than for conventional energy, with solar being more capital intensive.

When solar technology is introduced into the nation's economic system, it is more costly'in economic terms than the energy it displaces in all three cases because of its higher capital and labor requirements. Since the economy is operating at full capacity, solar's large capital and labor demands result in a certain amount of foregone production of other goods and services. The most serious economic costs occur in the User Pays Case. The Subsidy Case, while still imposing economic costs, is less severe. There is some economic loss in the Competitive Case, relative to the Base, because of the grefter capital requirements of solar energy over those of conventional spurces. However, these economic costs must be weighed against certain positive environmental and balanceof-trade benefits.

Several policy implications can be drawn from these preliminary results. If solar energy usage is going to be forced into the system, then subsidizing the differential cost is better than forcing the consumers to bear the difference. Also, if $\mathrm{RD} \& \mathrm{D}$ expenditures $\mathrm{c}$ an be allocated toward reducing the costs of solar devices, then solar usage imposes lower costs on the economy. 


\section{Renewable Technologies}

Currently in progress is a study examining the robustness of supply and demand policies with respect to renewable energy resources and conservation technologies, given several posstble paths which the energy system may take in the future. The uncertainties concerning future oil and gas prices, domestic oll and gas availabilities, and technological change in renewable and solar technologles are captured with a range of reference cases. Policies which attempt to decrease demand and policies which attempt to increase supply will be examined across this range for their effectiveness under the various reference cases and for their, impacts on the renewable and conservation technologies.

\section{SUMMARY}

This paper briefly describes the origins of and the rationale for the system of integrated models employed by Brookhaven National Laboratory and its application to a broad range of policy issues. Special attention is given to the ongoing efforts to develop more detailed demand components as their implementation is important in modeling conservation options. Several recent and current projects addressing conservation issues with all or part of this integrated system are described. 


\section{REFERENCES}

Behling, D. J., Analysis of Past and Expected Future Trends in U.S. Energy Consumption, 1947-2000, BNL 50725, 1977.

Behling, D. J. and G. Dennehy, Estimation of Final Demands and Current Input-Output Coefficients to 1985 , BNL $20369,1975$.

Behling, D. J. and R. Dullien, A Combined Linear Programming and Econometric Systems Analysis of the Relation Between Energy, Growth and the Economy, presented at Summer Computer Simulation Conference, BNL 21281, 1976.

Behling, D. J., R. Dullien, and E. Hudson, The Relationship of Energy Growth to Economic Growth Under Alternative Energy Policies, BNL 50500 , 1976.

Behling, D. J., W. Marcuse, 'J. Lukachinsk1, and R. Dullien, The long term economic consequences of phasing out nuclear electricity, in C.J. Hitch, Ed., Modeling Energy-Economy Interactions: Five Approaches, Resources for the Future, Washington, DC, 1977.

Behling, D. J., W. Marcuse, M. Swift, and R.G. Tessmer, A Two Level Iterative Model for Estimating Interfuel Substitution Effects, BNL 19863, 1975.

Beller, M., Ed., Sourcebook for Energy Assessment, BNL 50483, 1975.

Beller, M., E.A. Cherniavsky, K.C. Hoffman, and R.H. Williamson, Interfuel Substitution Study - The Role of Electrification, BNL 19522, 1974.

Braun, C., E.A. Cherniavisky, and F.T. Salżano, The Targer Cap1cal Costs tor the 1 mplementation of tuel lells and Electric Storage Devices Within the National Energy System, BNL 20523, 1975.

Bureau of Economic Analysis, U.S. Department of Comnerce, The inputoutput structure of the U.S. economy: 1967, Survey of Current Business, Vo1. 54, No. 2, pp. 24-56 (February 1975).

Bureau of Economic Analysis, U.S. Department of Commerce, The inputoutput structure of the U.S. economy: 1972, Survey of Current Business, Vo1. 59, No. 2, pp. 34-72 (February 1979).

Carhart, S.C., S.S. Mulherkar and Y. Sanborn, The Brookhaven Buildings Energy Conservation Optimization Model, BNL 50828, 1978.

Charles River Associates, Review and Evaluation of Selected Large Scale Mode1s, prepared for the Electric Power Research Institute, Charles RIver Associates, Cambridge, MA, 1977. 
Cherniavsky, E.A., Brookhaven Energy System Optimization Mode1, BNL $19569,1974$.

Cherniavsky, E.A., J. Davịdoff, and A.S. Kydes, Multi-ob.jective Function Analysis of ERDA Forecasting Year 2000 Scenario, BNL 50685, 1977.

Christensen, L. R. and D.W. Jorgenson, The measurement of real capital input, 1929-1967, Rev. Income and Wealth, Series 15, No. 4, pp. 293-320 (December 1969).

Christensen, L.R. and D.W. Jorgenson, U.S. real product and real factor input, 1929-1967, Rev. Income and Wealth, Series 16, No. 1, pp. 19-50 (March 1970).

Christensen, L. R. and D.W. Jorgenson, Measuring economic performance in the private sector, in M. Moss, Ed., The Measurement of Social and Economic Performance, Studies in Income and Wealth, No. 37, pp. 233-351, Columbia University Press, 1973a.

Christensen, L.R. and D.W. Jorgenson, U.S. income, saving, and wealth, 1929-1969, Rev. Income and Wealth, Series 19, No. 4, pp. 329-362 (December 1973b).

Coward, H. and F.T. Sparrow, The Aluminum Process Model, BNL, to be published.

Energy Modeling Forum, Energy and the Economy, Institute for Energy Studies, Stanford University, Stanford, CA, September 1977.

Energy Modeling Forum, Coal in Transition: 1985-2000, Institute for Energy Studies, Stanford University, Stanford, CA, July 1978.

Energy Policy Project of the Ford Foundation, A Time To Choose, Ballinger, Cambridge, MA, 1974.

ERDA-48, A National Plan for Energy Research, Development and Demonstration, The Energy Research and Development Agency, Washington, DC, 1975.

ERDA 76-1, A National Plan for Energy Research, Development and Demonstration, The Energy Research and Development Agency, Washington, DC, 1976.

Faucett, J. and Associates, Data Development for the I-0 Energy Model, Final Report to the Energy Policy Project, Washington, DC, May 1973.

Fraser, J.T., Documentation of the Brookhaven Energy $I-0$ and $I-0 / B E S O M$ Linkage, BNL 50856, 1978.

Goettle, R.J., E.A. Cherniavsky and R.T. Tessmer, An Integrated Mult1regional Energy and Interindustry Model of the United States,"BNL 22728 , May 1977. 
Goettle, R.J.,: P.J. Groncki, E.A. Hudson, and J. Lukachinski, A Comparative Long-Range Energy-Economy Projection, BNL 50989, 1979.

Goettle, R.J., E.A. Hudson, and J. Lukachinski, Comparative Assessment of Energy-Economy Interaction: Price vs. Growth, BNL 50923, 1978.

Goldberg, M.D., W.A. Sevian, A.W. Reisman, and P. Newhouse, The Energy Model Data Base Program, BNL 21545, 1976.

Groncki, P. J., A General Equilibrium Approach to Energy/Environmental Economic Analysis, BNL 24781, August 1978.

Hoffman, K.C. and D.W. Jorgenson, Economic and technological models for evaluation of energy policy, Bell J. of Econ., Vol. 8, No. 5, pp. 444466, (Autumn 1977).

Hudson, E.A. and D.J. Behling, Energy Conservation Yossibilities, Mechanisms and Impacts, BNL 50956, 1978.

Hudson, E.A. and D.W. Jorgenson, The Long-term Interindustry Transactions Model, Final Report to the Federal Preparedness Agency, Data Resources, Inc., September 1977.

Hudson, E.A. and D.W. Jorgenson, Energy prices and the U.S. economy, 1972-1976, Nat. Resources J., Vol. 18, No. 4, pp. 877-898, (October, 1978a).

Hudson, E.A. and D.W. Jorgenson,. The economic impact of policies to reduce U.S. economic growth, Resour. and Energy, Vol. 1, No. 3, pp. 205229, (1978b).

Hudson, E.A., D.W. Jorgenson, and D.C. O'Connor, The Dynamic Generalized Equilibrium Mode1, Linear Logarithmic Specification, Report to Federal Preparedness Agency, Data Kesources, Inc., 1978.

Jorgenson, D.W. and E.A. Hudson, U.S. energy policy and economic growth, Be11 J. Econ. Manage. Sci., Vol?. 5, No. 2, pp. 461-514, (Autumn 1974).

Jorgenson, L.W., L.J. Lau, and E.A. Hudson, Structure of Consumer Preferences (Interim Report), prepared for National Sclence Foundation, Data Resources, Inc., 1975.

Just, J., B. Borko, W. Parker, and A. Ashmore, New Technology Coeff1clents and Dynamic Energy Models, 2 Vol. prepared by the MITKE Corporation for the Energy Research and Development Administration, ERDA-3, Washington, DC, 1975.

Knect, R. L., Refinements on the Energy End Uses of Input-Output Model, Technical Memorandum 59, Center for Advanced Computation, University of I11inois, Urbana, 1975. 
Knect, R.L. and C.W. Bullard, End Uses of Energy in the U.S. Economy, 1967, CAC Document 145, Center for Advanced Computation, University of Illinois, Urbana, 1975.

Kydes, A.S., The Brookhaven Energy Systems Optimization Model, Its Variants and Uses, BNL 50873, 1978.

Kydes, A.S. and E.A. Chernfavsky, Coal in Iransition 1980-2000 Demand Considerations, BNL 50844, 1977.

Kydes, A.S. and J. Rabinowitz, The Time-stepped Energy System Optimization Model: A Topical Report, BNL, to be published.

Lukachinski, J. and R.G. Tessmer, 1985 Technical Coefficients for Inputs to Energy Technologies, BNL 50532, 1976.

Marcuse, W., S.C. Carhart, and S. Mulherkar, Residential Energy Demand Analysis-Data and Methodology, BNL $21920,1976$.

Marcuse, W., D.A. Pilati, and F.T. Sparrow, Energy Conservation - Technology Push or Policy Pull? Eng. Found. Conf., Henniker, NH, July 27, 1978 , to be published by the Library of Congress.

Marcuse, W., D.A. Pilati, and F.T. Sparrow, Validation issues - A view from the trenches, presented at DOE/NBS Validation Workshop,

Gaithersburg, MD (January 10, 1979).

Pilati, D.A. and R.A. Rosen, The Use of the Pulp and Paper Industry Process Model for R\&D Decision Making, BNL 50839, (1978a).

Pilati, D.A. and R. Rosen, Energy use modeling of the iron and steel industry," 1978 Summer Computer Simulation Conference, Newport Beach, CA, July 24-26 (April 1978b).

Schank, J., An Alternative, Semi-Automated Method For Performing Multiobjective Analysis, BNL 50892 , August 1978.

Sparrow, F.T., The Iron and Steel Industry Process Model, BNL, to be published.

Stanford Research Institute, Patterns of Energy Consumption in the United States, Menlo Park, CA, 1972.

Tessmer, R.G. and D.J. Behling, The Effects of Alternative Stockpiling Programs on the U.S. Economy, 1967-1979, BNL 50541, 1976.

Tcssmer, R.G., S.C. Carhare, and W. Marcuse, Economic Impacts of a Transition to Higher 0il Prices, BNL 50871, 1978. 
Tessmer, R.G., R.J. Goettle, A. Hermelee, J. Lukachinski, and S.C. Morris, Short Term Impacts of a National Nuclear Moratorium, BNL 21339 , 1976.

Tessmer, R.G., P. Groncki, and G. Boyce, Estimation of Sectoral Prices in the BNL Energy Input-Output Model, BNL $50768,1977$.

Tessmer, R.G., K.C. Hoffman, W. Marcuse, and D.J. Behling, Coupled Energy System-Economic Models and Strategic Planning, BNL $20120,1975$.

Tessmer, R.G. and J. Lukachinski, Economy-Wide Impacts of Interfuel Substitution of Electricity for Imported 011, BNL 50538, 1975.

Tessmer, R.G. and Y. Sanborn, Expanded 110 Sector Energy Input-0utput. Model, BNL 20354-R, 1975.

U.S. Department of Labor, Bureau of Labor Statistics, 134-order 1980 and 1985, Input-Output Forecasts, Unpublished data tapes, Washington, DC. 